\title{
Phenotypic plasticity of colour-patterned Plectodonta (Strophomenida, Brachiopoda) from the Lower Devonian of the Barrandian area (Czech Republic)
}

\author{
MICHAL MERGL \& LUCIE NOLČOVÁ
}

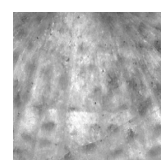

\begin{abstract}
Colour patterned shells of the strophomenide brachiopod Plectodonta mimica (Barrande, 1879) are described. The shells coming from the Kotýs Limestone (Lochkov Formation, Lochkovian) bear equidimensional spots spaced on shell surface in a divaricate pattern, in concentric bands or in combination of both, indicating high phenotypic variability. Coloration has been observed on ventral but rarely also in dorsal valves. Divaricate pattern of spots indicates that origin of spots is likely connected with neurosecretory function of the mantle. Similar origin is suggested for the truncated rugellae arranged in checkerboard pattern that are developed in some strophomenid brachiopods, e.g., Cymostrophia, Gunnarella, Ptychoglyptus, Sowerbyella (Rugosowerbyella). The camouflage function is not suggested for the colouration of Plectodonta because its ventral valve was likely faced downward. - Key words: Brachiopoda, Strophomenida, colour pattern, phenotypic plasticity, Devonian, Prague Basin, Bohemia.
\end{abstract}

Mergl, M. \& NolČovÁ, L. 2016. Phenotypic plasticity of colour-patterned Plectodonta (Strophomenida, Brachiopoda) from the Lower Devonian of the Barrandian area (Czech Republic). Bulletin of Geosciences 91(4), 653-660 (3 figures). Czech Geological Survey, Prague. ISSN 1214-1119. Manuscript received June 28, 2016; accepted in revised form October 13, 2016; published online November 29, 2016; issued February 7, 2017.

Michal Mergl, Faculty of Environmental Sciences, Czech University of Life Sciences Prague, Kamýcká 129, 16521 Prague, Czech Republic; argyrotheca@seznam.cz• Lucie Nolčová, Faculty of Environmental Sciences, Czech University of Life Sciences Prague, Kamýcká 129, 16521 Prague, Czech Republic; lucienolcova@ seznam.cz.

Colour patterned Lower Palaeozoic shells are generally rare. When observed, these finds are often published in particular contributions. In the Barrandian area of the Czech Republic, shells retaining colour pattern are known mostly among the Silurian and Devonian cephalopods (Barrande 1868-1870; Turek 2009; Manda \& Turek 2009a, b, 2011, 2015; Turek \& Manda 2010, 2012) and gastropods (Perner 1907, 1911; Kříž \& Lukeš 1974; Horný \& Henry 1999; Jankovský 2003). Colour markings interpreted as the original colour patterns were described also in the hyolith Ottomarites (Valent \& Malinky 2008) and the athyridid brachiopod Merista (Kř́ž \& Lukeš 1974), both also sampled in the early Devonian limestone of the Barrandian area.

Short review of the Devonian rhynchonelliform brachiopods retaining coloured shells was presented by Baliński (2010). In addition to eight genera of rhynchonellids, six genera of athyridids and 28 taxa of terebratulids reported by Baliński (2010) and observed or reviewed by other authors (Boucot \& Johnson 1968; Murphy 1972; Blodgett et al. 1983, 1988; Biernat 1984; Baliński 1985; Johnson 1986), the distinct radiating strips were described in terebratulidine by Baranov \& Blodgett (2011). There are no reports of colour patterned shells of Devonian or older representatives of strophomenids, orthids, pentamerids, atrypids, spiriferids, spiriferinidids or other large brachiopod groups. Therefore, the observation of Baliński (2010, 2012) on spotted plectambonitoidean Plectodonta mariae pantherae Baliński, 2012 from the earliest Devonian of Podolia, Ukraine is exceptional. The coloured Plectodonta mariae pantherae has been sampled in marly limestone of the Khudykivtsi Member about $5.5 \mathrm{~m}$ above the Silurian-Devonian boundary and represents the oldest known coloured brachiopods for strophomenid as well as for rhynchonelliformean brachiopods. The level with coloured Plectodonta mariae pantherae is only $18 \mathrm{~cm}$ in thickness. The associated fauna consists of 15 brachiopod species of which the most characteristic are Septatrypa (Septatrypa) secreta Kozlowski, 1929, Sphaerirhynchia gibbosa (Nikiforova, 1954), Clorinda pseudolinguifera Kozlowski, 1929, and Talentella crassiformis (Kozlowski, 1929) (Baliński, written communication). Other data about the brachiopod fauna given by Baliński $(2010,2012)$ indicate that the fauna represents a moderately diversified brachiopod association with many cosmopolitan genera of the Lochkovian age. 


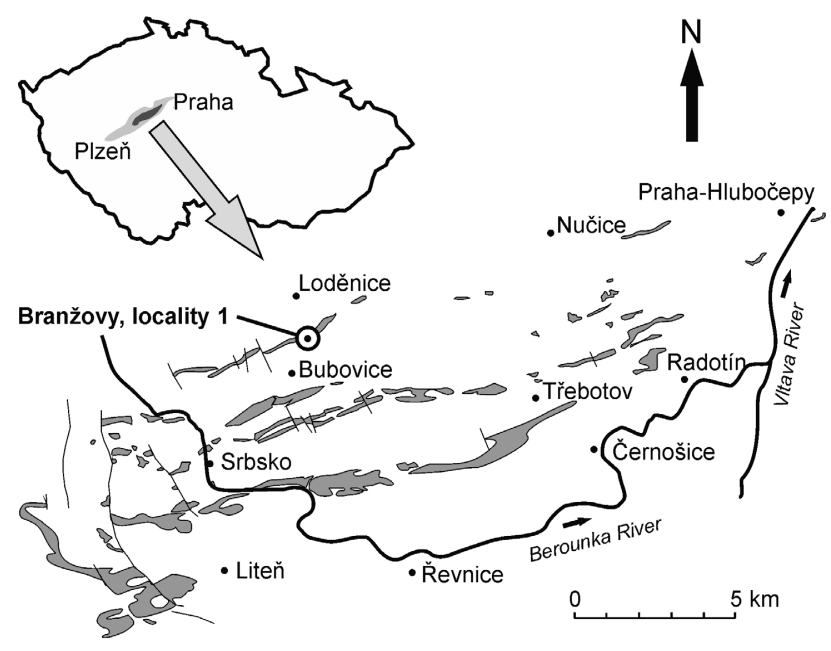

Figure 1. Schematic map showing the location of the Prague Basin in the Czech Republic and distribution of the Lochkov Formation with position of the sampled locality. Drawing of the Lochkov Formation distribution is based on geological maps 1:25,000 published by the Czech Geological Survey.

Recently, the similarly pigmented shells with remarkable phenotypic plasticity that belonging to a species Plectodonta mimica (Barrande, 1879) were observed in the Kotýs Limestone of the Lochkov Formation (Lochkovian) in the Barrandian area, the Czech Republic.

\section{Geological setting}

All specimens of coloured Plectodonta mimica have been sampled in the Kotýs Limestone of the Lochkovian age at the locality described by Mergl (2003) as the Branžovy, locality 1 . The site is situated in a short trench in the north side of a small abandoned quarry, $1200 \mathrm{~m}$ NE from Bubovice, on the $\mathrm{N}$ slope of a wooded ridge called Špičatý vrch (Fig. 1). The trench exposes a seventeen metres thick sedimentary succession composed of dark grey well-bedded micritic and grainstone limestone. Brachiopod coquinas are common in some limestone beds, but brachiopods are abundant throughout the section. Small, irregular, and lobate lenses of dark-grey chert are common in limestone. Limestone beds are steeply dipping to the $\mathrm{N}$ and are strongly weathered in the upper part of the trench. The coloured shell Plectodonta mimica were sampled in the lower part of the section, starting from the lowest exposed bed, with abundance decreases toward upper part of the section.

\section{Methods and material}

Silicified fossils from the locality have been prepared by chemical extraction from limestone. Hydrochloric acid in $10 \%$ solution, formic acid in $10 \%$ solution, and acetic acid in $10 \%$ solution have been used separately for various limestone samples. Despite different solutions, all residues yielded colour patterned shells of Plectodonta mimica. In total, several thousands of silicified brachiopod shells were picked from the residues, together with rare tabulate corals Squamifavosites, and four undescribed epibiont coral species. Trilobites, platyceratid gastropods and poorly preserved calyces and pluricolumnals of the crinoid Pisocrinus are rare. The costate atrypids Spinatrypa, Spinatrypina and costellate orthid brachiopods Dalejina, Isorthis, and Parmorthina are dominant in the section, but smaller brachiopods, especially Skenidioides, Dicoelosia, Muriferella, Atrypella, Navispira, Lissatrypa, and Nucleospira are also abundant. Strophomenids, pentamerids, rhynchonellids, spiriferids and athyridids are less abundant. High diversity of brachiopods (43 species including species of lingulates), with dominance of costate rhynchonelliformeans contrasts with low diversity of corals and rarity of other invertebrate groups. Presence of Skenidioides and Dicoelosia could indicate a deeper marine environment (BA 4-5 of Boucot 1975) but other brachiopods and abundance of corals indicates the photic zone (see Brett et al. 1993, 1999). Changes of the taxonomic composition through the section might be interpreted as a gradual shift from a shallower and sheltered environment with large strophomenids, orthotetids and pentamerids (e.g. Gypidula) to more open and agitated sea floor between normal and strom wave base with smallersized rhynchonelliformeans. The higher part of the section is characterised by low-diversity association dominated by the thick-shelled smooth atrypid Lissatrypa neglecta Havlíček, 1984 (Mergl 2003).

The colour pattern has been observed only in Plectodonta mimica (Barrande, 1879). Among 196 studied shells ( 2 articulated shells; 130 ventral valves and 66 dorsal valves), 118 valves show traces of spotted or banded colouration (86 ventral valves and 32 dorsal valves). This

Figure 2. Plectodonta mimica (Barrande, 1879); Lochkovian, Kotýs Limestone, Branžovy, locality 1 . • A, C-F - ventral valves with colour spots in oblique rows in radial and divaricate pattern, PCZCU 2053, PCZCU 2052, PCZCU 2054, PCZCU 2055, PCZCU 2062 • B - ventral valve with unspotted disc and marginal colour band, PCZCU 2056. - G-M - ventral valves with colour spots in early growth stages anterioly coalescent into concentric bands, PCZCU 2057, PCZCU 2058, PCZCU 2059, PCZCU 2060, PCZCU 2061, PCZCU 2051, PCZCU 2063. • N-R - ventral valves with concentric bands and rare coloured spots in early growth periods, PCZCU 2064, PCZCU 2065, PCZCU 2066, PCZCU 2067, PCZCU 2068. • S - ventral valve with concentric bands formed by chains of large coloured spots, PCZCU 2069. • T - dorsal valve showing spotted ornament, PCZCU 2070 . $\bullet$, V - dorsal valves showing concentric colour bands, PCZCU 2071, PCZCU 2072. Bar = $1 \mathrm{~mm}$; specimens uncoated by ammonium chloride. 

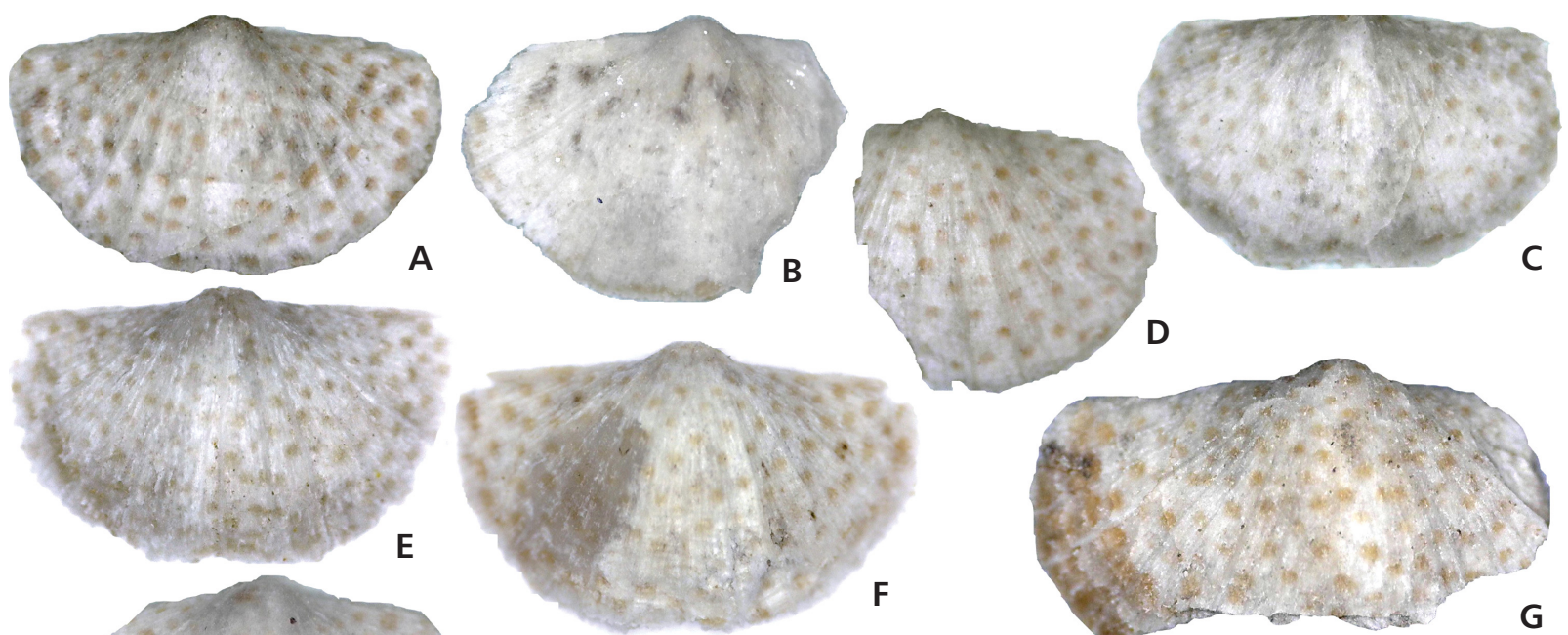

C
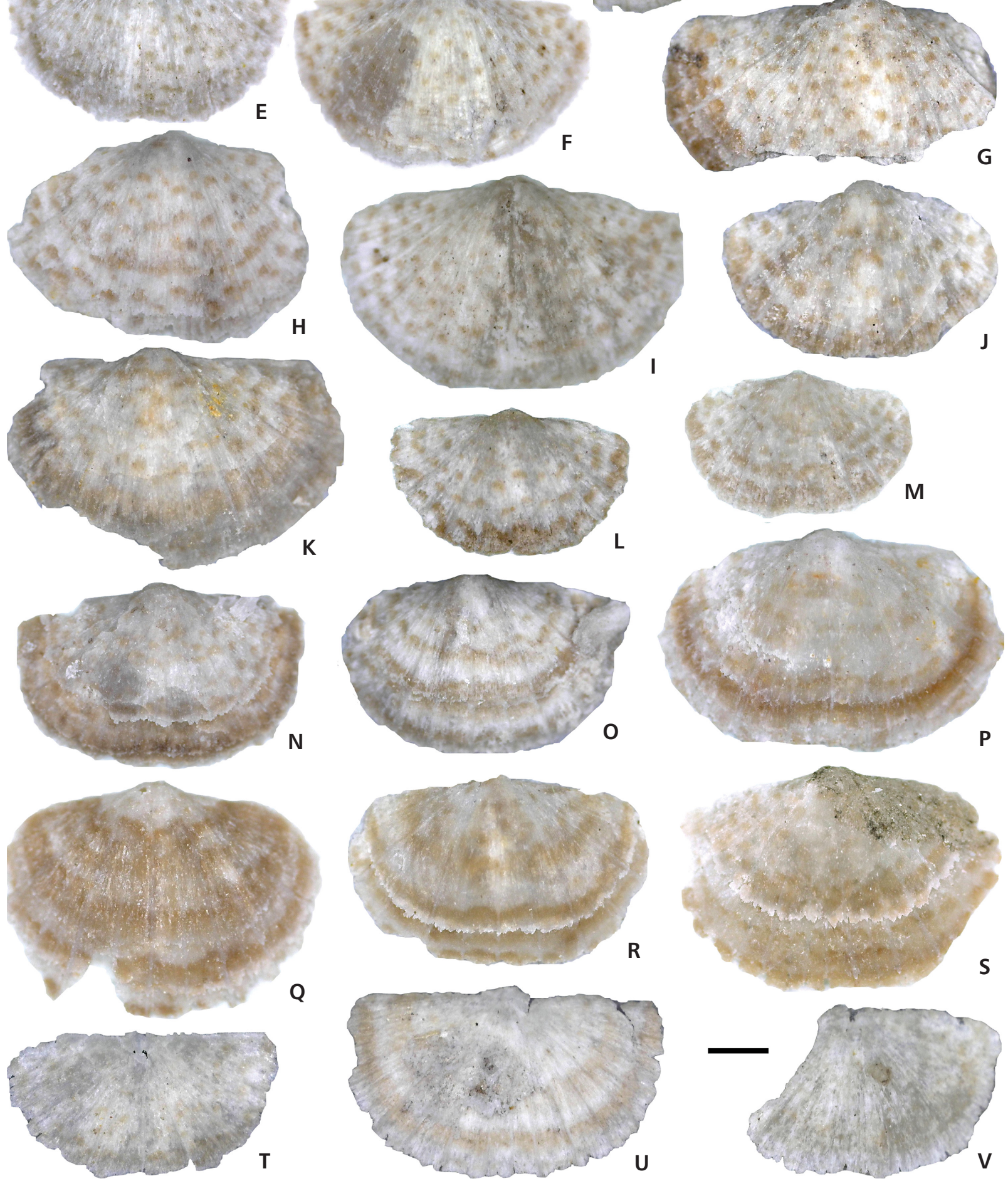
represents $60 \%$ of all sampled specimens. No shell of Plectodonta mimica shows trace of healed injury or circular boring hole evidencing a gastropod predation. Also associated brachiopods, except of one large ventral valve of Myriospirifer (Mergl 2003, pl. 18, figs 17, 18), lack any traces on healed injury.

\section{Phenotypic plasticity of colouration}

All colour patterned shells of Plectodonta mimica are silicified. It may look surprising that despite of the silicification an unambiguously original shell colour pattern of spots and concentric bands is so well preserved but it already has been known elsewhere (Yochelson \& Kř́ž 1974). Silicification even obscures the colour patterns (Fig. 2F, I, K). The more heavily silicified shell parts are medium to dark-grey in colour, slightly translucent and irregularly outlined. In contrast, the colour markings are pale orange-brown. Colour markings are more distinct on ventral valves than dorsal valves.

Ventral valves have a colourless beak. The first small $0.2 \mathrm{~mm}$ large spots appear immediately, in shells $\mathrm{ca}$ $0.9 \mathrm{~mm}$ wide. The spots are evenly scattered, in radial direction separated by colourless interspaces $0.3-0.5 \mathrm{~mm}$ wide. Colour spots are almost uniformly sized, $0.2 \mathrm{~mm}$ in diameter, with an irregularly round outline, and generally darker at their centre or nearby posterior margin. The periphery of spots gradually diffuses into adjacent light-grey shell. In 4-5 mm sized shells, the spots are arranged in radial rows separated by colourless primary costellae, with about 6 spots in a row. Some radial rows of spots bifurcate. The bifurcation is marked by larger spots followed by two smaller, spatially alternating spots in the new rows (Fig. 2A, left flank). Spacing of spots partially traces the growth lines. The result is a divaricate checkerboard pattern of colour spots on the entire shell. Discrete spots are generally but not always confined to interspaces between thin radial costellae. This basic distributional colour pattern may change with shell growth or within the population. Some shells (Fig. 2G, L, N) have discrete spots at older parts of the shell but spots become coalescent and form more or less distinct, wavy concentric bands in later growth stages. The colour in concentric lines is more intensive along the posterior margin of the line, where sharply contrasted with the earlier white shell. Anterior margins of the colour band are diffuse. Other shells lack spots except for few spots near the beak and the shells bear only entire wavy concentric bands. These bands are separated by wider or narrower bands of white shell. The coloration of colour bands may be interrupted by radial white arrays of the costellae (Fig. 2P, S). In extreme result, the concentric band may be formed by large diffuse spots (Fig. 2I). Phenotypic plasticity of the colouration is high and each shell keeps it own more or less distinct colouration pattern. Some shells having the same preservation are white except for a marginal concentric colour ridge. Such valves (Fig. 2B) apparently represent originally unspotted colourless specimens. It seems likely that some well preserved totally colourless valves represent the originally colourless shell but this cannot be demonstrated.

The dorsal valves are less distinctly coloured than the ventral valves. Most of the dorsal valves examined were colourless, but some shells have signs of smaller and less distinctive spots (Fig. 2T) or signs of lightly coloured concentric bands similar to bands preserved on the ventral valve (Fig. 2U, V). Both shells with conjoined valves exhibit the comparable distributions of spots on ventral and dorsal valves.

\section{Discussion}

The colour pattern of Plectodonta mimica (Barrande, 1879 ) is very similar to colour patterns of Plectodonta mariae pantherae described by Baliński $(2010,2012)$ on material of the comparable age (Lochkovian, Khudykivtsi Member of the Borshchiv Beds) from Podolia, Ukraine. However, the pigmentation pattern is not identical. The main difference is development of concentric bands in $P$. mimica. Similar bands are absent in $P$. mariae pantherae although Baliński (2010) noted coalescence of spots into the concentric chains (Baliński 2010; Fig. 1A). Similar passages of spot rows into continuous bands are known in a rhynchonellid Solidipontirostrum from the Middle Devonian of Poland (Biernat 1984). A further difference is a colourless dorsal valve in P. mariae pantherae. Plectodonta mimica has weak but clearly defined concentric bands and may bear weak but visible spots in the dorsal valve. However, this difference may be somewhat debatable because the evaluation of phenotypic variability may be puzzling in the fossil material. Although Baliński's (2010) and our samples are comparably sized (170 and 182 specimens, respectively), the dorsal valves represent only one-third of specimens studied. Similar to observation on $P$. mariae pantherae, the intensity of spot colouration is higher on the ventral valve of $P$. mimica than the dorsal valve. Baliński (2012) discussed the differences in the external morphology between $P$. mariae pantherae and $P$. mimica. We confirm that the shell of $P$. mimica is larger, with width up to $7 \mathrm{~mm}$ and lacks the alate outline, but both species are closely related.

The difference in the coloration combined with the assumed camouflage function between the ventral and dorsal valves led Baliński (2010) to the conclusion that the life position of $P$. mariae pantherae was convex (= ventral) valve up. This calls in question the generally accepted position with the concave-up position of plectambonitoideans, 
and in a broader sense, the strophomenate brachiopods (Rudwick 1970, Bassett 1984). Convex valve-up position has been suggested by Lescinsky (1995) due analysis of epibionts in some orthides and strophomenides. The traditional view was also called into question by Dattilo (2004) in his observation of the Ordovician plectambonitoid Sowerbyella preserved with burrow-like structures in a vertical position, followed by Datillo et al.'s (2009) analysis of Rafinesquina alternata having a ventral valve convex-up position. However, there are evidences of opposite attitude, with convex down ventral valve (Leighton 1998), but the discussion about both possibilities continues (Datillo 2006, Leighton 2006). Hoel (2005) discussed the life position of strophomenides and argues that convex up position is simply the hydrodynamically stable position also of the dead shells on sediment surface. Obviously, the convex-up position is stable and therefore optimal for settlement of larval stages of epibionts and may differ from the original position of the living brachiopod. The convex-up position could not be the life position of the living strophomenids because the aperture would be in direct contact with the sediment (Hoel 2005). The opposite convex-down attitude is directly evidenced by the preserved life position of some leptaenids and early douvillinids in the Silurian of Gotland (Hoel 2005, 2007). His conclusions might be generalized also for other concavo-convex strophomenids. Other indirect evidence favouring a concave-up position of Plectodonta is its homoeomorph with chonetidine brachiopods. Many chonetidine brachiopods are similarly sized and shaped, with concavo-convex shells but having tubular hollow spines along the posterior margin of the ventral valve. In assumed convex-up position, by lifting of the convex ventral valve in opening shell process, the spines should move and penetrate inside the substrate. That is unlikely from a mechanical view. The extremely long spines of some chonetidine genera (Andalucinetes Racheboeuf, 1985; Babinia Racheboeuf \& Branisa, 1985; Chlupacina Havlíček \& Racheboeuf, 1979; Pseudostrophochonetes Racheboeuf, 1981) clearly argue against a convex-up position of the chonetidines and, likely, the plectambonitoidean Plectodonta.

Further Baliński (2010) speculates that the camouflage function of the colouring of Plectodonta mariae pantherae makes sense only within the photic zone. The lower limit of the photic zone correlated with the BA 3-4 in Boucot (1975) classification is suggested by Baliński (2012) for the brachiopod association of the Khudykivtsi Member. This brachiopod association, although less diversified, differs little from the brachiopod association of the Kotýs Limestone from Bohemia. The atrypid Spinatrypa senilis (Havlíček, 1987) is common in both areas and Skenidioides tatyanae Baliński, 2012 is closely related to $S$. famulus Havlíček, 1977. The approximately comparable depth range we suggest for the brachiopod association of the Kotýs Limestone, but pres-

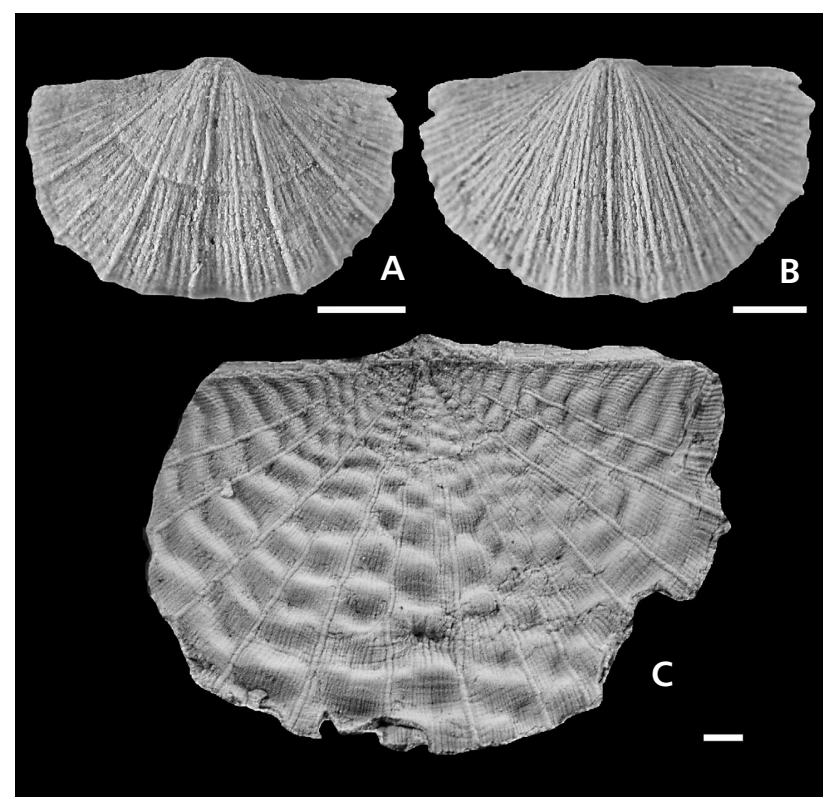

Figure 3. A, B - Plectodonta mimica (Barrande, 1879), Lochkovian, Kotýs Limestone, Branžovy, locality 1; ventral valves, exterior, showing primary coarser costellae, PCZCU 2055, PCZCU 2062. - C - Cymostrophia stephani (Barrande, 1848); Pragian, Koněprusy Limestone, Koněprusy, Na Voskopě hill. Dorsal valve, exterior, showing truncated rugellae and checkerboard pattern of ornamentation, PCZCU 2073. Bar = $1 \mathrm{~mm}$; specimens coated by ammonium chloride.

ence of Dicoelosia and rarity of rhynchonellid brachiopods pointed to slightly deeper or/and more low energy environment than expected in Podolia.

If the defense strategy of Plectodonta had been based on camouflage coloration of the shell, this would suggest response to a predators which preferred the optical signals in a photic zone. In a deeper part of the photic zone, the red or brownish spots of Plectodonta shell actually appeared black. However, assuming the convex-down position of Plectodonta with the more intensively spotted ventral valve down then spots could not have the camouflage function. Spotted ventral valves faced downward and buried in the sediment does not make sense for the camouflage function.

It is noteworthy, that the distribution of pigmented colour spots in Plectodonta mimica and P. mariae pantherae mimetises the relief checkerboard ornamentation pattern known in some strophomenids. Sowerbyella (Rugosowerbyella) Mitchell, 1977 has an ornament of concentric rugae truncated by offset by accentuated costae that is very similar to spotted shell of Plectodonta. The Silurian genus Ptychoglyptus Willard, 1928 has small rugellae interrupted by costellae, forming remarkably coarse checkerboard pattern. Also other strophomenide genera [Bellimurina Cooper, 1956; Cymostrophia Caster, 1939; Gunnarella Spjeldnaes, 1957; Katastrophomena Cocks, 1968; Pentlandina Bancroft, 1949; Pterostrophia Garrat, 1985; Shaleria (Janiomya) Havlíček, 1967] exhibit the similarly truncated 
rugellae (Fig. 3) forming the checkerboard pattern. We could speculate that depressions of checkerboard structure of these genera were filled by small amount of sediment or depression were accentuated by darker pigmented spots of the shell. This checkerboard pattern visually disintegrate the otherwise distinct semicircular outline of a brachiopod shell. Spatial distribution of spots on Plectodonta shells follows the same strategy of the shell outline disintegration. Instead of possibly (?) metabolically more costly relief changes of shell wall, Plectodonta used only coloured spots for outline disintegration. Absorption of the red colour of the visible spectrum in the water column effectively produced dark spots on Plectodonta shells from depths of a few metres.

However, if we do not adopt the suggestion about the convex-up position the spotted convex valve of Plectodonta and the camouflage function of spots on its shell, what was the primary function of the pigmented spots? The spots, despite some level of irregularity (Baliński 2010) appear rather periodically within the narrow sector bounded by primary costellae. Alternation of colourless and coloured shell surface is regular and follows the divaricate pattern. Indeed, the colour spots in $P$. mimica and $P$. mariae pantherae have not so random a distribution as dark spots in some cowrie shells, e.g., famous Cypraea tigris Linnaeus, 1758.

In discussion about origin and primary function of the regular pigmentation pattern of bivalve and gastropod shells authors have suggested the automatic origin and presented the mathematic models of such pattern (Waddington \& Cove 1969, Seilacher 1972, Ermentrout et al. 1986). There are speculations but also evidences (Bauchau 2001, Boettiger et al. 2009, Boettiger \& Oster 2009), that the origin of divaricate spots and pigment lines is controlled by neurosecretory system and it is connected with the developmental stability mechanism of the animal. The periodic pattern is created by cycles of stimulation and quiescence of secreting-stimulating neurons. A plot of the current pigmentation versus the past pigmentation traces out a single loop around which the system continuously cycles. A mechanistical explanation of the many of pattern changes is given in detail by Boettiger et al. (2009). Likely, as in some molluscs, the Hopf bifurcation combined with Turing instabilities (Ermentrout 1998, Boettiger et al. 2009) are the most plausible explanation for the Plectodonta spotted pattern. The same mechanism might explain the truncated rugella and checkerboard like relief surface of some strophomenides. The neurosectory function may change with the time and modify shell shape. The retardation of shell growth induced the coalescence of spots and formation of observed concentric colour bands in Plectodonta mimica. In some Silurian strophomenids characteristically exemplified by Shaleria (Janiomya), the distinctness of truncated rugellae decreases forwards (Hoel 2011). It is noteworthy, the variability of distinctness of truncated rugellae in Shaleria (Janiomya) ornatella (Davidson, 1871) from Silurian of Gotland (Hoel 2005) brings the evidence about unique control of their formation among individuals in a population. This indicates that the neurosecretory system likely underwent changes with the age of the specimen and differs among individuals in population. Change of neurosectory activity with age of individuals is also evidenced in Cymostrophia stephani (Barrande, 1848) from the Pragian of the Bohemia (Fig. 3C). Its checkerboard pattern is present at the shell disc representing a developmental stage preceding the formation of the trail. The trail alone bears only radial ornament of primary costellae with thinner secondary costellae in narrow sectors in between (Havlíček 1967).

The pigmentation patterns of recent bivalves and gastropods are often hidden under the periostracum cover, and are not easily visible. Some extant animals live inside the sediment and the colour pattern indeed lacks the camouflage (cryptic) function as the visual signal. Therefore, the camouflage is the secondary function, with some examples reviewed by Seilacher (1972). In summary, not all spotted shells have pigmented spots for the camouflage purpose. The spotted pattern and the truncated rugellae (= checkerboard surface) of Palaeozoic strophomenate brachiopods may simply reflect the periodicity of neurosecretal activity during shell growth and had, at least primarily, no camouflage functions. Their utilization for protective camouflage, if any, was secondary and seems unlikely for Plectodonta in connection with a supposed mode of life with ventral valve down.

\section{Conclusion}

Distinct phenotypic plasticity of colouration has been observed in Plectodonta mimica, a common plectambonitoidean in the Lower Devonian Kotýs Limestone (Lochkovian) in the Barrandian area. Colour patterns consist of small distinct spots arranged in a divaricate pattern with coalescent spots forming the concentric bands in the larger shells. Colourless shells were likely present in the original population as suggested colour intensity variation.

Baliński's (2010) argument for camouflage, based on colouration and concerning the habitat of Plectodonta mariae pantherae at depths within the photic zone with shell in convex-up position on sea floor seems implausible. The spotted surface of $P$. mimica and checkerboard surface of strophomenids is much more likely related to the activity of neurosecretory system of the animal and primary has no primary camouflage function. Colour spotted shells of Plectodonta might be the optical substitute of the relief-based checkerboard pattern of some Palaeozoic plectambonitoids and strophomenids, but their primary camouflage function is debatable. 
We also suggest, based on similarity of the pigmented patterns, that shell formation and pigment secretion in brachiopods and molluscs is controlled by the same mechanism related to neural and secretory systems.

\section{Acknowledgements}

We are grateful to Andrzej Baliński and Carl Brett for many helpful comments on the manuscript. This study was supported by a grant of the Grant Agency of the Czech Republic GAČR P210-12-2018 (for M.M.). This is a contribution to IGCP Project 591: The Early to Middle Palaeozoic Revolution.

\section{References}

BALIŃSKI, A. 1985. Shell color pattern in an Upper Devonian rhynchonellid brachiopod. Acta Palaeontologica Polonica 30, 241-244.

BALIŃSKI, A. 2010. First colour-patterned strophomenide brachiopod from the earliest Devonian of Podolia, Ukraine. Acta Palaeontologica Polonica 55(4), 695-700.

DOI 10.4202/app.2010.0066

BALIŃSKI, A. 2012. The brachiopod succession through the Silurian-Devonian boundary beds at Dnistrove, Podolia, Ukraine. Acta Palaeontologica Polonica 57(4), 897-924.

DOI 10.4202/app.2011.0138

BANCROFT, B.B. 1949. Welsh Valentian brachiopods and the Strophomena antiquata group of fossil brachiopods. 16 pp. Privately printed, Mexborough.

Baranov, V.V. \& BlodgetT, R.B. 2011. Gonella, a new genus and first color patterned terebratulidine brachiopod from the Lower Devonian of Northeast Asia. Bulletin of Geosciences 86(2), 269-274. DOI 10.3140/bull.geosci.1258

BARRANDE, J. 1848. Ueber die Brachiopoden der silurischen Schichten von Böhmen. Naturwissenchaftliche Abhandlungen, Part 2, 153-256. W. Haidinger, Wien.

BARRANDE, J. 1868-1870. Systême silurien du Centre de la Bohême. Ière partie: Recherches paléontologiques. Volume 2. Cephalopodes, série 2, 8. 266 pp. Prague.

BARRANDE, J. 1879. Systême silurien du Centre de la Bohême. Ière partie: Recherches paléontologiques. Volume 5. Classe des Mollusques. Ordre des Brachiopodes. 226 pp. Prague \& Paris.

BASsetT, M.G. 1984. Life strategies of Silurian brachiopods. Special Papers in Palaeontology 32, 237-263.

Bauchau, V. 2001. Develepmental stability as the primary function of the pigmentataion patterns in bivalve shells? The Belgian Journal of Zoology 131 (suppl.) (2), 23-28.

Biernat, G. 1984. Colour pattern in the Middle Devonian rhynchonellid brachiopods from the Holy Cross Mts. Acta Geologica Polonica 34, 63-72.

Blodgett, R.B., Boucot, A.J. \& Ferrill, B.A. 1983. A colorbanded Beachia (Brachiopoda: Terebratulida) from the Oriskany equivalent (mid-Early Devonian) of Central Alabama. Journal of Paleontology 57, 865-869.

Blodgett, R.B., Boucot, A.J. \& Koch, W.F. 1988. New occurrences of color patterns in Devonian articulate brachiopods. Journal of Paleontology 62, 46-51. DOI $10.1017 /$ S0022336000017984
Boettiger, A., Ermentrout, B. \& Oster, G. 2009. The neural origin of shell structure and pattern in aquatic molluscs. Proceedings of the National Academy of Sciences of the United States of America 106(6), 6837-6842. DOI 10.1073/pnas.0810311106

Boettiger, A. \& Oster, G. 2009. Emergent complexity in simple neural systems. Communicative \& Integrative Biology 2(6), 1-4. DOI 10.4161/cib.2.6.9260

Boucot, A.J. 1975. Evolution and extinction rate controls. 427 pp. Balkema, Elsevier.

Boucot, A.J. \& Johnson, J.G. 1968. Evidence of color banding in a Lower Devonian rhynchonellid brachiopod. Journal of Paleontology 42, 1208-1209.

Brett, C.E., Boucot, A.J. \& Jones, B. 1993. Absolute depths of Silurian benthic assemblages. Lethaia 26, 25-40. DOI 10.1111/j.1502-3931.1993.tb01507.x

CASTER, K.E. 1939. A Devonian fauna from Colombia. Bulletins of American Paleontology 24, 1-218.

Cocks, L.R.M. 1968. Some strophomenacean brachiopods from the British Lower Silurian. British Museum (Natural History), Bulletin (Geology) 19(4), 142-203.

Cooper, G.A. 1956. Chazyan and related brachiopods. Smithsonian Miscellaneous Collection 127, 1-1245.

DAVIDSON, T. 1871. A Monograph of the British fossil Brachiopoda, Vol. 3, Part 7, Silurian. Palaeontographical Society Monograph 4, 249-397.

Datillo, B.F. 2004. New angle on strophomenid palaeoecology: trace-fossil evidence on an escape response for the plectambonitoid brachiopod Sowerbyella rugosa from a tempestite in the Upper Ordovician Kope Formation (Edenian) of Northern Kentucky. Palaios 19, 332-384.

DOI 10.1669/0883-1351(2004)019<0332:ANAOSP >2.0.CO;2

DAtillo, B.F. 2005. Reply - a new angle on strophomenid palaeoecology: trace-fossil evidence on an escape response for the plectambonitoid brachiopod Sowerbyella rugosa from a tempestite in the Upper Ordovician Kope Formation (Edenian) of Northern Kentucky. Palaios 20, 601-604.

Datillo, B.F., Meyer, D.L., Dewig, K. \& Gaynor, M.R. 2009. Escape traces associated with Rafinesquina alternata, an Upper Ordovician strophomenid brachiopod from the Cincinnati Arch Region. Palaios 24(9), 578-590.

DOI 10.2110/palo.2008.p08-102r

ERmentrout, B. 1998. Neural networks as spatio-temporal pattern-forming systems. Reports on Progress in Physics 61, 353-430. DOI 10.1088/0034-4885/61/4/002

Ermentrout, B., Campbell, J. \& Oster, G. 1986. A model for shell patterns based on neural activity. The Veliger 28(4), 369-388.

Garrat, M.J. 1985. Pterostrophia, a new early Devonian douvillinid brachiopod from the Humevale Formation, Lilydale, Victoria, Australia. Journal of Paleontology 59(3), 523-530.

HavlíčEK, V. 1967. Brachiopods of the Suborder Srophomenidina in Czechoslovakia. Rozpravy Ústředního ústavu geologického 33, 1-235.

HaVLíčEK, V. 1977. Brachiopods of the order Orthida in Czechoslovakia. Rozpravy Ústředního ústavu geologického 44, $1-327$.

HaVlíčEK, V. 1984. Lissatrypa (Brachiopoda; Silurian, Lower Devonian) in Bohemia. Věstník Ústředního ústavu geologického 59(4), 217-225.

HavlíčEK, V. 1987. Lower Devonian and Eifelian Atrypacea (Brachiopoda) in central Bohemia. Sborník geologických věd, Paleontologie 28, 61-115. 
HavlíčeK, V. \& Racheboeuf, P. 1979. Chonetacea (Brachiopodes) du Silurien et du Dévonien de Bohême (Tchécoslovaquie). Annales de Paléntologie, Invertebrés 65(2), 69-138.

HoEl, O.E. 2005. Diversity and life habits of Silurian strophomenide brachiopods of Gotland. 47 pp. MS Ph.D. thesis, Uppsala University, Uppsala, Sweden.

HoEl, O.E. 2007. Cementing strophomenide brachiopods from the Silurian of Gotland (Sweden): Morphology and life habits. Geobios 40, 589-608. DOI 10.1016/j.geobios.2006.08.003

Hoel, O.E. 2011. Strophomenidae, Leptostrophiidae, Strophodontidae and Shaleriidae (Brachiopoda, Strophomenida) from the Silurian of Gotland, Sweden. Paläontologische Zeitschrift 85, 201-229. DOI 10.1007/s12542-010-0088-3

HoRnÝ, R. \& HenRY, J.-L. 1999. A letter by Joachim Barrande to Daniel Oehlert concerning Praenatica (Gastropoda) written on May, 1882. Journal of the Czech Geological Society 44(1-2), 177-125.

JANKOvSKÝ, M. 2003. Shell morhology and palaeocology of Praenatica gregaria Perner, 1903 from the Koněprusy Limestone (Lower Devonian) of Bohemia (Czech Republic). Bulletin of Geosciences 78(4), 423-429.

Johnson, J.G. 1986. Revision of Lower Devonian (Emsian) brachiopod biostratigraphy and biogeography, central Nevada. Journal of Paleontology 60, 825-844. DOI 10.1017/S0022336000042979

Kozlowski, R. 1929. Les Brachiopodes gothlandiens de la Podolie Polonaise. Palaeontologia Polonica 1, 1-254.

KŘiž, J. \& LuKEš, P. 1974. Color patterns on Silurian Platyceras and Devonian Merista from the Barrandian Area, Bohemia, Czechoslovakia. Journal of Paleontology 48, 41-48.

Leighton, L.R. 1998. Constraining functional hypotheses: controls on the morphology of the concavo-convex brachiopod Rafinesquina. Lethaia 31(4), 293-307. DOI 10.1111/j.1502-3931.1998.tb00519.x

Leighton, L.R. 2005. Comment - a new angle on strophomenid palaeoecology: trace-fossil evidence on an escape response for the plectambonitoid brachiopod Sowerbyella rugosa from a tempestite in the Upper Ordovician Kope Formation (Edenian) of Northern Kentucky. Palaios 20, 596-600. DOI 10.2110/palo.2005.p05-C2

LESCINSKY, H.L. 1995. The life orientation of concavo-convex brachiopods; overturning the paradigm. Paleobiology 21, 520-551. DOI 10.1017/S009483730001352X

LinNÉ, C. 1758. Systema naturae per regna tria naturae, secundum classes, ordines, genera, species, cum characteribus, differentiis, synonymis, locis. Editio decima, reformata. 824 pp. Laurentii Salvii, Holmiae. DOI 10.5962/bhl.title.542

Manda, Š. \& Turek, V. 2009a. A Silurian oncocerid with preserved colour pattern and muscle scars (Nautiloidea). Bulletin of Geosciences 84(4), 755-766.

DOI 10.3140/bull.geosci.1168

MANDA, S̆. \& TuREK, V. 2009b. Minute Silurian oncocerid nautiloids with unusual colour patterns. Acta Palaeontologica Polonica 54, 503-512. DOI 10.4202/app.2008.0062

MANDA, Š. \& TUREK, V. 2011. Colour pattern polymorphism in Silurian nautiloid Phragmoceras Broderip, 1839. Bulletin of Geosciences 86(1), 91-105. DOI 10.3140/bull.geosci.1240

Manda, Š. \& TureK, V. 2015. Colour patterns on Silurian oncocerid and pseudorthocerid conchs from Gotland - palaeoecological implications. Estonian Journal of Earth Sciences 64(1), 74-76. DOI 10.3176/earth.2015.13
Mergl, M. 2003. Silicified brachiopods of the Kotýs Limestone (Lochkovian) in the Bubovice area (Barrandian, Bohemia). Acta Musei nationalis Pragae, Series B - historia naturalis 59(3-4), 99-150.

Mitchell, W.I. 1977. Ordovician Brachiopoda from Pomeroy, Co. Tyrone. Monograph of the Palaeontographical Society 130, 1-138.

MurPhy, J.L. 1972. A Lower Devonian (Oriskany) brachiopod with color markings. Ohio Journal of Science 72, 296-299.

Nikiforova, O.I. 1954. Stratigrafiya i brakhiopody siluriiskikh otlozhenii Podolii. Trudy vsesoyuznogo nauchno-issledovatelskogo geologicheskogo instituta (VSEGEI), 1-218.

Perner, J. 1907. Gastéropodes. In Barrande, J. Systême silurien $d u$ Centre de la Bohême, Volume IV, tome 2. 380 pp. Prague.

Perner, J. 1911. Gastéropodes. In Barrande, J. Systême silurien du Centre de la Bohême, Volume IV, tome 3. 390 pp. R. Gerhard, Leipsic \& Fr. Rivnáč, Prague.

Racheboeuf, P.R. 1981. Chonetacés (Brachiopodes) siluriens et dévoniens du Sud-Ouest de l'Europe. Mémoires de la Société géologique et minéralogique de Bretagne 27, 1-294.

Racheboeuf, P.R. 1985. Andalucinetes hastatus nov. gen., nov. sp., nouveau Chonetacea (Brachiopoda) dévonien du Sud-Ouest de l'Espagne. Geobios 18(5), 659-664. DOI 10.1016/S0016-6995(85)80063-2

Racheboeuf, P.R. \& Branisa, L. 1985. New data on Silurian and Devonian chonetacean brachiopods from Bolivia. Journal of Paleontology 59, 1426-1450.

Rudwick, M.J.S. 1970. Living and Fossil Brachiopods. 199 pp. Hutchinson \& Co. Ltd., London.

SeIlacher, A. 1972. Divaricate pattern in pelecypod shells. Lethaia 5, 325-343.

DOI 10.1111/j.1502-3931.1972.tb00862.x

SpJeldnaes, N. 1957. The Middle Ordovician of the Oslo region, Norway. 8, Brachiopods of the Suborder Strophomenida. Norsk geologisk Tiddskrift 37, 1-214.

TureK, V. 2009a. Colour patterns in Early Devonian cephalopods from the Barrandian area: Taphonomy and taxonomy. Acta Palaeontologica Polonica 54, 491-502. DOI 10.4202/app.2007.0064

TuReK, V. \& MANDA, Š. 2010. Variability of colour pattern and shell abnormalities in Silurian nautiloid Peismoceras Hyatt, 1884. Journal of the National Museum (Prague), Natural History Series 179(16), 171-178.

TuREK, V. \& MANDA, Š. 2012. "An endocochleate experiment" in the Silurian straight-shelled cephalopod Sphooceras. Bulletin of Geosciences 87(4), 767-813.

DOI 10.3140/bull.geosci.1335

Valent, M. \& Malinky, J.M. 2008. Early Devonian (Emsian) hyolith Ottomarites discors (Barrande, 1867) with colour pattern. Bulletin of Geoscinces 83(4), 503-506. DOI 10.3140/bull.geosci.2008.04.503

WiLLARD, B. 1928. The brachiopods of the Ottosee and Holston formations of Tennessee and Virginia. Bulletin of the Harvard Museum of Comparative Zoology 68, 255-292.

Waddigton, C.H. \& Cowe, R.J. 1969. Computer simulation of a molluscan pigmentation pattern. Journal of Theoretical Biology 25, 219-225. DOI 10.1016/S0022-5193(69)80060-3

Yochelson, E.L. \& KŘíž, J. 1974. Platyceris gastropods from the Oriskany Sandstone (Lower Devonian) near Cumberland, Maryland; synonymies, preservation and color markings. Journal of Paleontology 48(3), 474-484. 